\title{
Aquatic oligochaetes (Annelida: Clitellata) in reservoirs in São Paulo State: list of occurrence and ecological observations on the species
}

\author{
Douglas Aparecido Girolli ${ }^{1}{ }^{\circledR}$, Mariana Futenma de Lima ${ }^{1 \oplus}$, Nathalie Aparecida de Oliveira Sanches ${ }^{1}$, \\ Vanessa Colombo-Corbi ${ }^{1}$, Juliano José Corbi ${ }^{2} \&$ Guilherme Rossi Gorni $^{1}$ \\ ${ }^{1}$ Universidade de Araraquara, Programa de Pós-graduação em Desenvolvimento Territorial e Meio Ambiente, \\ CEP 14801-340, Araraquara, SP, Brasil \\ ${ }^{2}$ Universidade de São Paulo, Departamento de Hidráulica e Saneamento, Escola de Engenharia de São Carlos, \\ CEP 13566-590, São Carlos, SP, Brasil \\ *Corresponding author: douglasgirolli@gmail.com
}

GIROLLI, D.A, LIMA, M.F., SANCHES, N.A.O., COLOMBO-CORBI, V., CORBI, J.J., GORNI, G.R. Aquatic oligochaetes (Annelida: Clitellata) in reservoirs in São Paulo State: list of occurrence and ecological observations on the species. Biota Neotropica 21(3): e2021. https://doi.org/10.1590/1676-0611-BN-2020-1152

\begin{abstract}
This work sought the survey of species and information about the distribution of the Class Oligochaeta in reservoirs sampled in the Sediment Quality Monitoring Network of CETESB (Environmental Company of the State of São Paulo). As such, this study aimed to inventory the limnic oligochaetes fauna to expand knowledge of the ecology and distribution of this group in reservoirs in the state of São Paulo. Ninety replicates were performed in 12 reservoirs in the state of São Paulo between 2014 and 2016, using van Veen or Ponar samplers in the sublittoral region, and Ekman-Birge in the deep region. Twenty-eight taxa were inventoried, belonging to the families Naididae and Opistocystidae. The species Dero righii and Pristina longisoma were recorded for the first time in São Paulo State, Nais magnaseta and Spirosperma velutina were first recorded in Brazil. The results presented here make this inventory extremely important for understanding the distribution of aquatic oligochaetes throughout the Brazilian territory.
\end{abstract}

Keywords: distribution; bioindicators; diversity; reservoir; inventory.

\section{Oligoquetos aquáticos (Annelida: Clitellata) em reservatórios no Estado de São Paulo: lista de ocorrência e observações ecológicas das espécies}

\begin{abstract}
Resumo: Este trabalho buscou o levantamento de espécies e informações sobre a distribuição da Classe Oligochaeta em reservatórios amostrados na Rede de Monitoramento da Qualidade de Sedimentos da CETESB (Companhia Ambiental do Estado de São Paulo). Sendo assim, este estudo objetivou inventariar a fauna de oligoquetos para expandir o conhecimento de ecologia e distribuição deste grupo em reservatórios no Estado de São Paulo. Foram realizadas 90 réplicas em 12 reservatórios no estado de São Paulo entre os anos de 2014 a 2016, utilizando amostradores van Veen ou Ponar na região sublitoral, e Ekman-Birge na região profunda. Foram inventariados 28 táxons, pertencentes às famílias Naididae e Opistocystidae. As espécies Dero righii e Pristina longisoma, foram registradas pela primeira vez no Estado de São Paulo, Nais magnaseta e Spirosperma velutina foram identificadas pela primeira vez no Brasil. Os resultados apresentados aqui tornam este inventário de suma importância para o conhecimento da distribuição dos oligoquetos aquáticos em todo o território brasileiro.
\end{abstract}

Palavras-chave: distribuição; bioindicadores; diversidade; reservatório; inventário. 


\section{Introduction}

Species surveying is essential for understanding the biota of a given environment, specifically in Brazilian aquatic ecosystems where species diversity is poorly known due to the small number of taxonomists (ROCHA, 2003; AGOSTINHO et al., 2005). Although oligochaetes are among the most abundant species in sediments of Neotropical lakes and reservoirs, there is relatively poor ecological information, especially in comparison to the knowledge generated in temperate-zone habitats where these species are used to monitor water quality (BRINKHURST; GELDER 1991, MARTIN et al., 2008, CHRISTOFFERSEN, 2010, TIMM; MARTIN 2015, RODRIGUES; ALVES 2018). The community composition and structure of the Class Oligochaeta provides important information for the assessment of water and sediment quality, and has therefore proved to be a great tool for aquatic biomonitoring (LAFONT, 1989; ROSSO, 1995; PRYGIEL et al., 2000; VIVIEN et al., 2014). Despite their representativeness in aquatic macroinvertebrate fauna, oligochaetes are poorly studied compared to other benthic groups (GORNI, 2007), however, several authors have been collecting information about the diversity and ecology of the Oligochaeta assemblage in São Paulo State (MARCUS DU BOIS-REYMOND MARCUS, 1949; RIGHI, 1984; CORBI et al., 2004; PAMPLIN et al., 2005; DORNFELD et al., 2006; ALVES; GORNI, 2007; SURIANI et al., 2007; GORNI; ALVES, 2007; GORNI; ALVES, 2008b; GORNI; ALVES, 2006; GORNI, 2007; GORNI et al., 2015; GIROLLI et al., 2018).

Given this, gathering information about the assemblages of oligochaetes is essential for knowledge of limnic biodiversity, assessment and water management. To provide information to environmental management bodies and facilitate decision-making on recovery and / or preservation of Brazilian aquatic ecosystems.

Thus, this article aims to inventory the diversity of Class Oligochaeta species in lentic environments of São Paulo State monitored by CETESB, as well as contribute to the knowledge of distribution and ecological observations in the State of São Paulo.

\section{Material and Methods}

\section{Area of study}

The Oligochaeta fauna samples were granted for the purpose of this research by the Aquatic Communities Sector (ELHC) and are part of the Sediment Quality Monitoring Network of CETESB. Twelve reservoirs were studied in the state of São Paulo between 2014 and 2016, where a total of 90 replicates were collected. Reservoir identification is described in Table 1, and the location of the points is illustrated in Figure 1.

\section{Physical and Chemical Variables}

The physical and chemical variables were collected in two groups, water and sediment. The variables collected in the water were: total surface phosphorus (P), bottom dissolved oxygen (DO), bottom electrical conductivity (EC), chlorophyll a (C), and depth (Dep). The variables collected in the sediment were: sediment organic matter $(\mathrm{OM})$, total organic carbon (TOC), total Kjeldahl nitrogen $(\mathrm{NKj})$, total phosphorus (Ptot) and granulometry were performed and determined by CETESB. The bibliography and analytical methods used to collect and determine the variables are available in Annex E of the Relatório da Qualidade das Águas Interiores no Estado de São Paulo (CETESB, 2017). The values of the environmental variables measured were tested using multivariate variance analysis (MANOVA) to identify possible significant differences between the collected points.

The Trophic State Index (IET) was used to classify the water quality of the reservoirs for nutrient enrichment. The IET is composed of the indices of the Trophic State for phosphorus - IET (PT), and for

Table 1. Identification of sampling points of the Sediment Quality Monitoring Network of São Paulo State reservoirs, conducted by CETESB from 2014 to 2016. Ugrhi - Water Resources Management Unit; N - sampling effort.

\begin{tabular}{|c|c|c|c|c|c|}
\hline \multirow{2}{*}{ Site } & \multirow{2}{*}{ Reservoirs } & \multirow{2}{*}{ Coordinate } & \multirow{2}{*}{ Ugrhi } & \multicolumn{2}{|c|}{$N$} \\
\hline & & & & Sublittoral & Deep \\
\hline BILL & Billings - Central body & $23^{\circ} 47^{\prime} 11^{\prime \prime S} / 46^{\circ} 38^{\prime} 49^{\prime \prime} \mathrm{W}$ & 6 & 3 & 3 \\
\hline BIRP & Billings - Rio pequeno & $23^{\circ} 47^{\prime} 28^{\prime \prime} \mathrm{S} / 46^{\circ} 28^{\prime} 14^{\prime \prime} \mathrm{W}$ & 6 & 6 & 6 \\
\hline BITQ & Billings - Taquacetuba & $23^{\circ} 50^{\prime} 26^{\prime \prime} \mathrm{S} / 46^{\circ} 39^{\prime} 31^{\prime \prime} \mathrm{W}$ & 6 & - & 3 \\
\hline CAFR & França & $23^{\circ} 56^{\prime} 01^{\prime \prime} \mathrm{S} / 47^{\circ} 09^{\prime} 28^{\prime \prime} \mathrm{W}$ & 11 & 3 & 3 \\
\hline GRAM & Graminha & $21^{\circ} 35^{\prime} 06^{\prime \prime} \mathrm{S} / 46^{\circ} 37^{\prime} 04^{\prime \prime} \mathrm{W}$ & 4 & 3 & 6 \\
\hline IUNA & Paraibuna & $23^{\circ} 25^{\prime} 06^{\prime \prime} \mathrm{S} / 45^{\circ} 34^{\prime} 17^{\prime \prime} \mathrm{W}$ & 2 & 3 & 3 \\
\hline JQJU & Paiva Castro & $23^{\circ} 21^{\prime} 13^{\prime \prime} \mathrm{S} / 46^{\circ} 39^{\prime} 56^{\prime \prime} \mathrm{W}$ & 6 & 6 & 6 \\
\hline JURU & Jurumirim & $23^{\circ} 16^{\prime} 28^{\prime \prime} \mathrm{S} / 49^{\circ} 04^{\prime} 05^{\prime \prime} \mathrm{W}$ & 14 & 3 & 3 \\
\hline NOVA & Ponte Nova & $23^{\circ} 34^{\prime} 46^{\prime \prime} \mathrm{S} / 45^{\circ} 57^{\prime} 02^{\prime \prime} \mathrm{W}$ & 6 & 3 & 3 \\
\hline PEBA & Taiaçupeba & $23^{\circ} 34^{\prime} 45^{\prime \prime} \mathrm{S} / 46^{\circ} 17^{\prime} 30^{\prime \prime} \mathrm{W}$ & 6 & - & 3 \\
\hline RGDE & Rio grande & $23^{\circ} 44^{\prime} 30^{\prime \prime} \mathrm{S} / 46^{\circ} 24^{\prime} 59^{\prime \prime} \mathrm{W}$ & 6 & - & 3 \\
\hline SANT & Santa Branca & $23^{\circ} 22^{\prime} 15^{\prime \prime} \mathrm{S} / 45^{\circ} 51^{\prime} 35^{\prime \prime} \mathrm{W}$ & 2 & 3 & 3 \\
\hline SOIT & Itupararanga & $23^{\circ} 37^{\prime} 08^{\prime \prime} \mathrm{S} / 47^{\circ} 23^{\prime} 22^{\prime \prime} \mathrm{W}$ & 10 & 3 & 3 \\
\hline TIPR & Promissão & $21^{\circ} 18^{\prime} 49^{\prime \prime} \mathrm{S} / 49^{\circ} 45^{\prime} 49^{\prime \prime} \mathrm{W}$ & 16 & 3 & 3 \\
\hline
\end{tabular}

Fount: Adapted from the São Paulo State Inland Water Quality Report (CETESB, 2015, 2016 and 2017). 


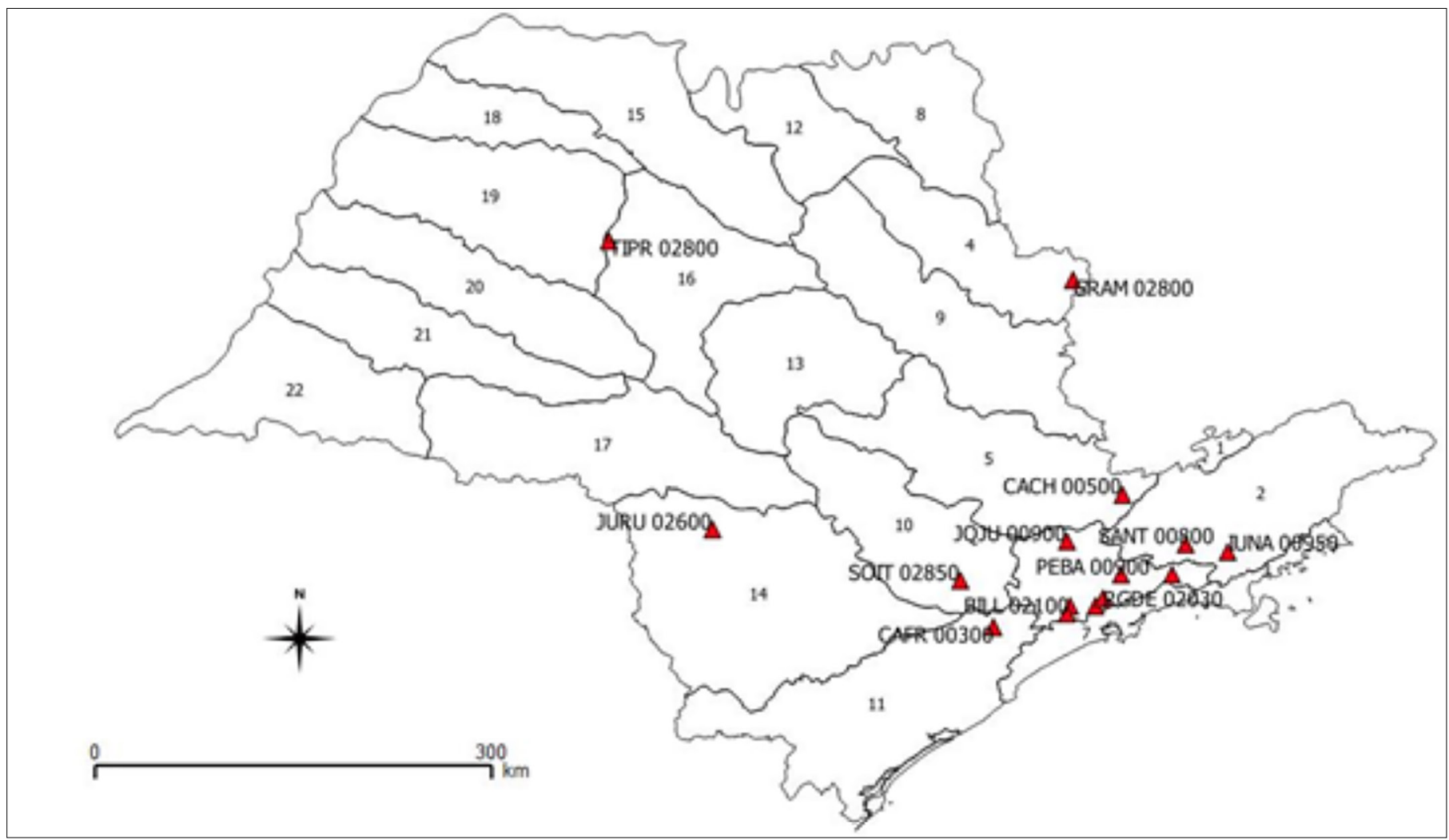

Figure 1. Spatial distribution of the sampling points of the Sediment Quality Monitoring Network of São Paulo State reservoirs, conducted by CETESB from 2014 to 2016.

chlorophyll a - IET (CL). Thus, the result of the IET is the arithmetic mean between the IET (PT) and IET (CL) indices, with their respective equations:

$$
\begin{aligned}
& \operatorname{IET}(P T)=10\{6-[1,77-0,42 .(\operatorname{InPTIn} 2)]\} \\
& \operatorname{IET}(C L)=10\{6-[0,92-0,34 .(\operatorname{In} C L \operatorname{In} 2)]\} \\
& \operatorname{IET}=[\operatorname{IET}(\mathrm{PT})+\operatorname{IET}(C L)] 2
\end{aligned}
$$

where: $P T=$ total phosphorus concentration measured at the water surface, expressed in $\mu \mathrm{g} / \mathrm{L} ; C L=$ chlorophyll concentration at total measured at the water surface, expressed in $\mu \mathrm{g} / \mathrm{L}$; and $\ln =$ natural logarithm.

\section{Oligochaeta Collection and Identification}

The sediment samples for analysis of Oligochaeta assemblage were collected by CETESB with van Veen or Ponar sewers in the sublittoral region and Ekman-Birge in the deep region. The fixation and sample preparation followed the CETESB Technical Standard L5.309 (CETESB, 2003). For the identification of the organisms the taxonomic criteria adopted by Brinkhurst and Jamieson (1971), Righi (1984), Brinkhurst and Marchese (1989) and Timm (2009) were used.

To evaluate the efficiency of the samples collected in the reservoirs, species richness estimators (Jackknife 1 and 2, Bootstrap) and randomized species accumulation curves (collector curve) were used. Species accumulation curves were constructed using 100 curves generated by the random addition of the samples, using the software "R" version 3.1.1 (R CORE TEAM, 2017).

We applied a Boxplot chart and selected the most abundant species (upper quartile) to perform a descriptive analysis of the reservoirs in which these species were found.

\section{Results and Discussion}

The means of environmental variables (depth, sand, silt, clay, organic matter, dissolved oxygen, total surface phosphorus, total sediment phosphorus, electrical conductivity, chlorophyll a, total organic carbon, total Kjeldahl nitrogen, and trophic state index), as well as the standard deviation, are exposed in Table 2. The same variables were submitted to a Multivariate Variance Analysis (MANOVA), in which a significant difference was identified between the points $(p<0.05)$, which means that the reservoirs are statistically different from the environmental variables presented above.

As for the Trophic State Index, the highest values were recorded in two regions of the Billings reservoir. The first was in the central body (72.9) and in the Taquacetuba arm (70.8), they were classified as Hypereutrophic, followed by the Rio Grande (65.6) and PEBA (63.4) reservoirs, which were classified as Supereutrophic. However, all other reservoirs showed a degree of nutrient enrichment, since the lowest IET class recorded was Mesotrophic. None of the reservoirs were classified as Ultraoligotrophic or Oligotrophic.

The highest values of the variables OM (20.2\%), EC (204), P (0.15 mg / L), Ptot (5,573 mg / Kg) and C (93.56 $\mu \mathrm{g} / \mathrm{L})$ and the lowest value of DO $(3.1 \mathrm{mg} / \mathrm{L})$ were recorded in the central body of the Billings reservoir. Other reservoirs, such as SANT and JURU, had opposite values for the same variables.

The assemblage of oligochaetes inventoried in this study was composed of two families (Naididae and Opistocystidae) distributed in 28 species. The sample design adopted in the present study can be considered adequate for species survey, since the accumulation curve stabilized in 70 samples. Figure 2 illustrates the species accumulation curve and richness estimators.

The Naididae family presented $96 \%$ of the found taxa $(n=27)$, being represented by the subfamilies Naidinae, Pristininae, Rhyacodrilinae 


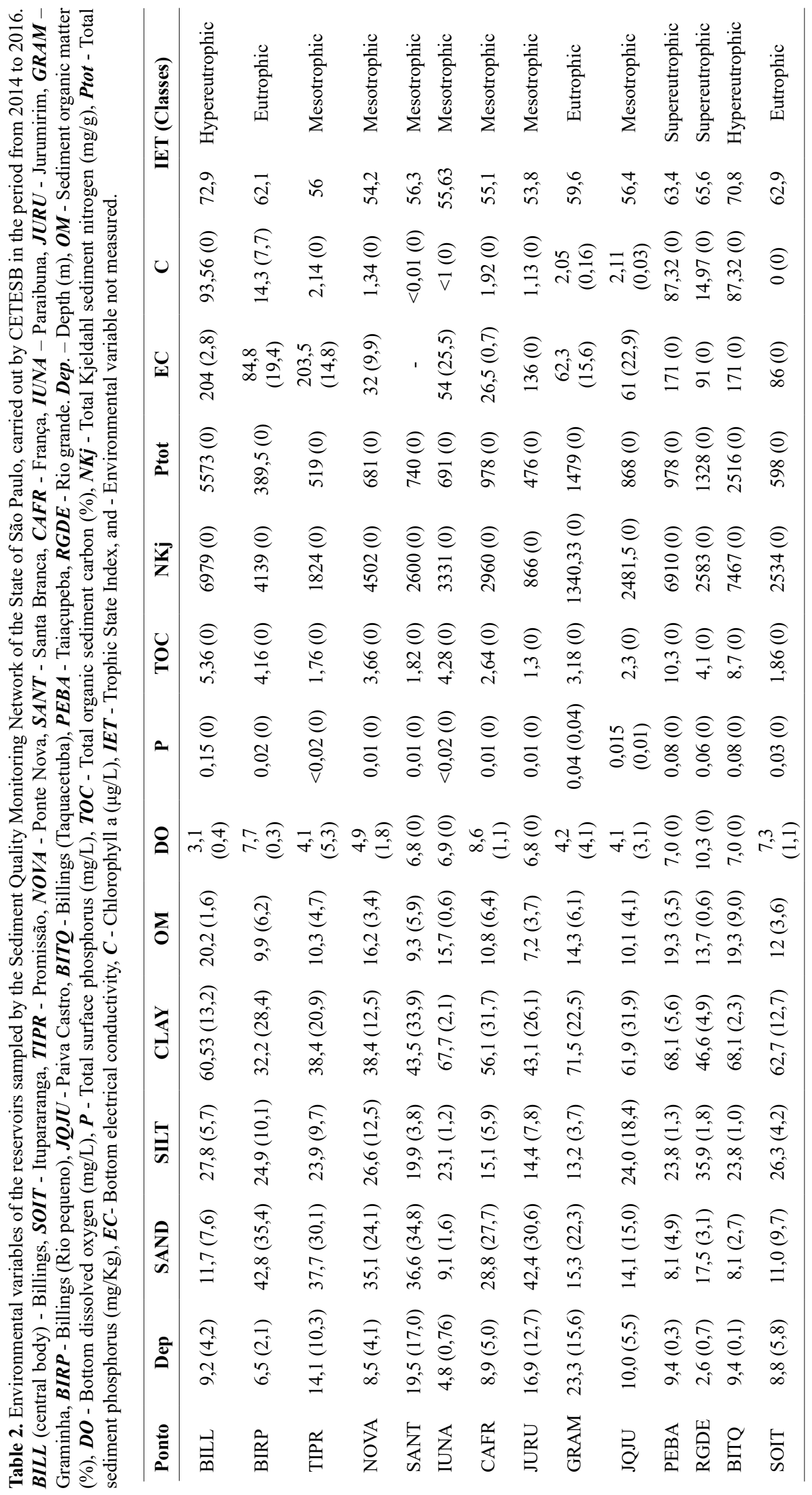


and Tubificinae. Among the Naidids, the subfamily Naidinae, which represented $59 \%$ of the species $(\mathrm{n}=16)$, was composed by the genera Aulophorus, Chaetogaster, Dero, Nais, Slavina and Stephensoniana. The subfamily Pristininae presented $22 \%$ of species $(n=6)$, represented by its only genus (Pristina). The subfamily Rhyacodrilinae was represented by the taxa, Bothrioneurum sp. and Branchiura sowerbyi, corresponding to $7 \%$ of the identified species. Finally, the subfamily Tubificinae was represented by the genera Aulodrilus, Limnodrilus and Spirosperma making up $11 \%$ of the identified species $(n=3)$. The Opistocystidae family was represented by only one species, Opistocysta funiculus, corresponding to $4 \%$ of the identified species.

Among the 28 species identified in this study, Dero righii and Pristina longisoma had not been registered in the state of São Paulo, occurring only in the states of Mato Grosso do Sul, Minas Gerais and Paraná, and Mato Grosso do Sul and Paraná, respectively. Two other species had not been recorded in Brazil, Nais magnaseta whose knowledge of their distribution was restricted to Texas, USA (Harman, 1973); and Spirosperma velutina, whose distribution was registered in Venezuela and Europe (CHRISTOFFERSEN, 2007).

The species identified in this study, as well as the record of their ecological observations in the State of São Paulo, are presented below distributed in family, genus and species, following alphabetical order. The synonym list was based on the catalog proposed by Christoffersen (2007).

The species recorded with the highest abundances recorded in the upper quartile of the boxplot were Aulodrilus pigueti (40.4\%); Bothrioneurum sp. (13,7\%); Limnodrilus hoffmeisteri (11.9\%); Opistocysta funiculus (8.9\%); Pristina osborni (4.4\%) and Pristina synclites (4.3\%). Table 3 shows the reservoirs where these species were found.

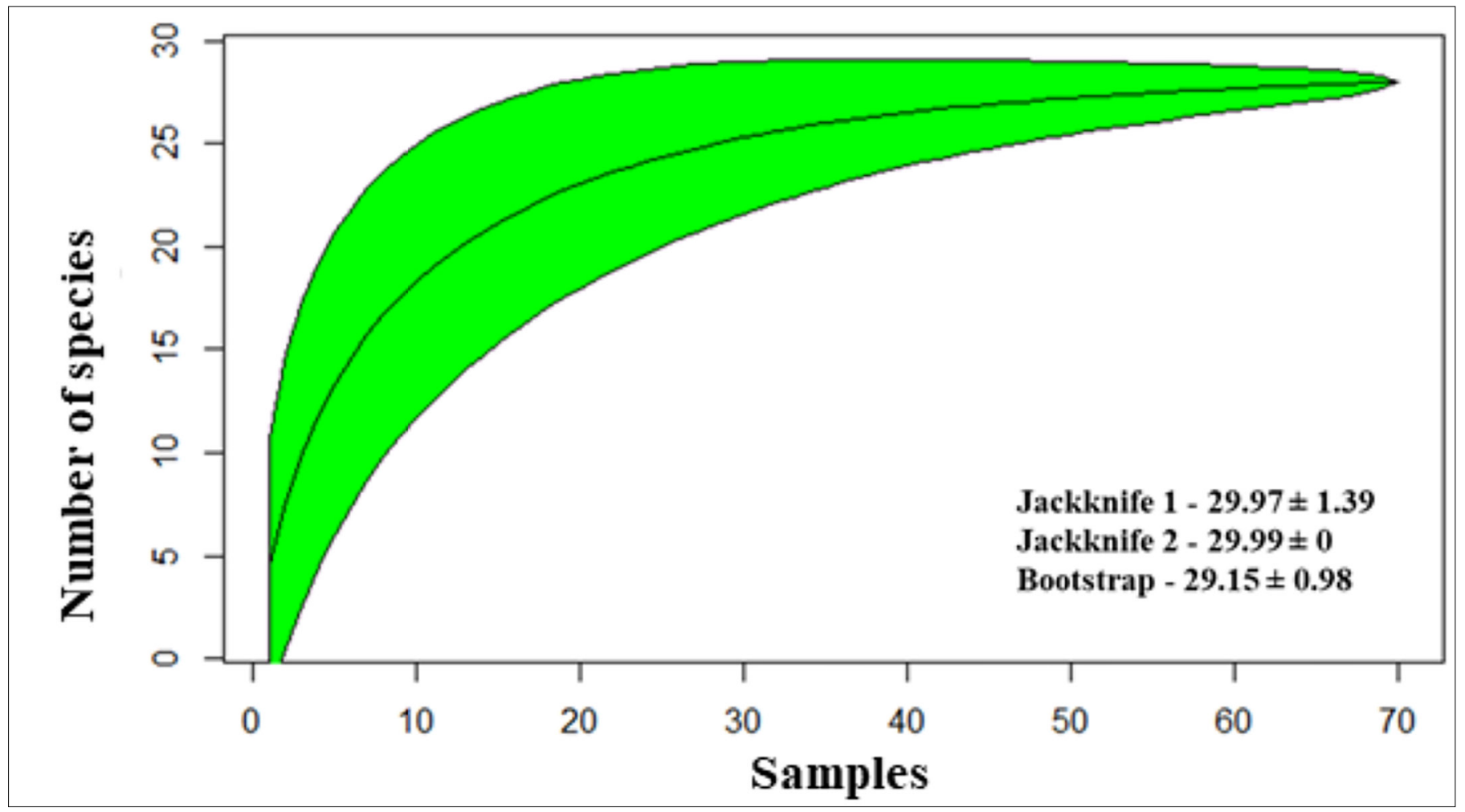

Figure 2. Species accumulation curve and richness estimators for oligochaetes collected at the sampling points of the Sediment Quality Monitoring Network of São Paulo State reservoirs, conducted by CETESB from 2014 to 2016.

Table 3. Occurrence of the most abundant species of Oligochaeta in reservoirs in the State of São Paulo. BILL - Billings, SOIT - Itupararanga, TIPR - Promissão, NOVA - Ponte Nova, SANT - Santa Branca, IUNA - Paraibuna, CAFR - França, JURU - Jurumirim, GRAM - Graminha, $\boldsymbol{B I R P}$ - Billings (Rio pequeno), JQJU - Paiva Castro, BITQ - Billings (Taquacetuba), PEBA - Taiaçupeba, $\boldsymbol{R} \boldsymbol{G D E}$ - Rio grande. Presence (X).

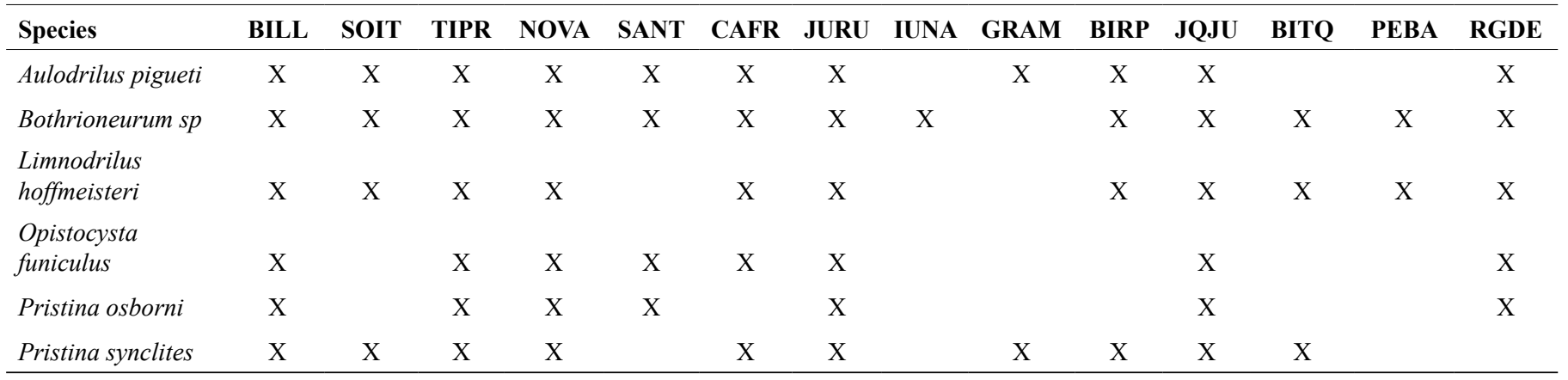




\section{List and species considerations}

\section{NAIDIDAE FAMILY Ehrenberg, 1828 \\ NAIDINAE SUBFAMILY}

Aulophorus borelli Michaelsen, 1900.

Synonyms: Dero sp. Cognetti, 1900; Dero borelli Michaelsen, 1900; Aulophorus borellii Michaelsen, 1900; Dero (Aulophorus) borellii Michaelsen, 1900.

Record and ecological observations: Found associated with sediment in Araraquara, Santa Clara stream (ALVES; LUCCA, 2000); associated with Scirpus cubensis (Cyperaceae), Luiz Antônio, Infernão Lake (CORREIA; TRIVINHO-STRIXINO, 1998; TRIVINHOSTRIXINO et al., 2000); Associated with Salvinia (Salviniaceae) and Egeria (Hydrocharitaceae), Américo Brasiliense, Anhumas stream dam (SANCHES; GORNI, 2014). We found it in Promissão and Billings reservoirs.

Aulophorus costatus Du Bois-Reymond Marcus, 1944.

Synonyms: Aulophorus schmardai f. costata Du Bois-Reymond Marcus, 1944; Dero (Aulophorus) costatus Du Bois-Reymond Marcus, 1944; Dero (Aulophorus) schmardai, Harman, 1974.

Record and ecological observations: Found in São Paulo, in the Pinheiros river (DU BOIS-REYMOND MARCUS, 1944; MARCUS, 1942; 1943); associated with submerged macrophytes in Brotas, at Lagoa Dourada dam (ALVES; GORNI, 2007), and with Salvinia (Salviniaceae) and Egeria (Hydrocharitaceae) in Américo Brasiliense, at Anhumas stream dam (ALVES; GORNI, 2007; SANCHES; GORNI, 2014); associated with Metania spinata (Metaniidae) in Itirapina, in the Dourada Lake dam (GORNI; ALVES, 2008a). We found it in Paiva Castro, Jurumirim and Graminha reservoirs.

Aulophorus furcatus O. F. Müller, 1774.

Synonyms: Nais furcata O. F. Müller, 1774. Dero (Aulophorus) furcatus O. F. Muller, 1774; Dero sp. Stephenson, 1910; Aulophorus stephensoni Michaelsen, 1912; Dero roseola Nicholls, 1921.

Record and ecological observations: Found in Bariri, in the Ponte Nova reservoir (PAMPLIN et al., 2005), in São Paulo in the Tietê, Pinheiros, São Lourenço rivers in Jardim Europa sewage (MARCUS, 1943), and in a stream of Bocaina (SANCHES et al., 2016). Associated with Pomacea bridgesii (Ampullaridae) in Araraquara (GORNI; ALVES, 2006); and the sediment in Barra Bonita (SURIANI et al., 2007). We found it in the Graminha and Billings reservoirs.

Chaetogaster diaphanus Gruithuisen, 1828.

Synonyms: Nais diaphana Gruithuisen, 1828.

Record and ecological observation: Found associated with the Pomacea bridgesii (Ampullaridae) in Araraquara (GORNI; ALVES, 2006); associated with Salvinia (Salviniaceae) and Egeria (Hydrocharitaceae) in the Anhumas stream dam, in Américo Brasiliense (SANCHES; GORNI, 2014). We found it in the Cachoeira do França, Rio Grande and Graminha reservoirs.

Dero digitata O. F. Müller, 1773.

Synonyms: Nais digitata O. F. Müller, 1773; Dero (Dero) digitata O. F. Müller, 1773; Nais (Proto) digitata O. F. Müller, 1773; Uronais digitata O. F. Müller, 1773; Proto digitata O. F. Müller, 1773; Xantho hexapoda Dutrochet, 1819; Dero limosa Leidy, 1852; Dero acuta Bousfield, 1886; Dero michaelseni Svetlov, 1924; D. bonariensis
Michaelsen, 1933; D. kawamurai Kondô, 1936; Dero tanimotoi Kondô, 1936; Dero quadribranchiata Cernosvitov, 1937.

Record and ecological observations: Found in Bariri, in the Ponte Nova reservoir (PAMPLIN et al., 2005), and in São Paulo, in the São Lourenço river (ROSA et al., 2015). Associated with sediment in Bariri, in the Ponte Nova reservoir (SURIANI et al., 2007); associated with submerged macrophytes in Brotas, at Lagoa Dourada Dam, and in Américo Brasiliense, at Anhumas stream dam (ALVES; GORNI, 2007); in Salvinia (Salviniaceae) and Egeria (Hydrocharitaceae) (SANCHES; GORNI, 2014). In Araraquara, was found associated with sediment in Santa Clara stream (ALVES; LUCCA, 2000); and Pomacea bridgesii (Ampullaridae) (GORNI; ALVES, 2006). We found it in the reservoirs Graminha, Promissão and Billings.

Dero evelinae Marcus, 1943.

Synonyms: Dero (Dero) evelinae Marcus, 1943.

Record and ecological observations: Found in São Paulo (MARCUS, 1942, 1943, 1944). Associated with sediment in the Bariri reservoir (SURIANI et al., 2007) and in São Carlos, in the Fazzari dam (FUSARI; FONSECA-GESSNER, 2006); associated with submerged macrophytes in Brotas, at Lagoa Dourada Dam, and in Américo Brasiliense, at Anhumas stream dam (ALVES; GORNI, 2007); and associated with Scirpus cubensis (Cyparaceae) (CORREIA; TRIVINHO-STRIXINO, 1998; TRIVINHO-STRIXINO et al., 2000). We found it in the Promission reservoir and in the central body of the Billings reservoir.

Dero multibranchiata Stieren, 1892.

Synonyms: Dero florifera Oken, 1815.

Record and ecological observations: Found associated with sediment in Bariri (SURIANI et al., 2007), at Ponte Nova reservoir (PAMPLIN et al., 2005), in Américo Brasiliense, at Anhumas stream dam (CORBI; TRIVINHO- STRIXINHO, 2002). We found it in the Billings reservoir, and in the arm of Taquacetuba.

Dero righii Varela, 1990.

Synonyms: Dero (Dero) righi Varela, 1990.

Record and ecological observation: This species was first registered in the state of São Paulo. The reservoirs where D. righii occurred were Billings - Rio Pequeno, Graminha, Taiaçupeba, Rio Grande, Itupararanga, Ponte Nova, and Paiva Castro. In previous studies, this species occurred in the states of Mato Grosso do Sul (TAKEDA et al., 2000); Minas Gerais (MARTINS; ALVES, 2008); and Paraná (RAGONHA; TAKEDA, 2014).

Dero Sawayai Marcus, 1943.

Synonyms: Dero heterobranchiata Michaelsen, 1933; Dero (Dero) sawayai Marcus, 1943.

Record and ecological observations: Found associated with the Pinheiros River sediment (MARCUS, 1943); in Araraquara was found associated with Pomacea bridgesii (Ampullaridae) (GORNI; ALVES, 2006); associated with submerged macrophytes at Lagoa Dourada dam in Brotas, and at Anhumas stream dam in Américo Brasiliense (ALVES; GORNI, 2007); and associated with Metania spinata (Metaniidae) in Itirapina in Dourada Lake (GORNI; ALVES, 2008a). We found it in 
the Itupararanga, Paiva Castro, Rio Grande, Graminha, Promissão and Billings - Rio Pequeno reservoirs.

Nais communis Piguet, 1906.

Synonyms: Nais heterochaeta Benham, 1893; Nais Walton, 1906; Nais parviseta Walton, 1906; Nais variabilis var. punjabensis Stephenson, 1909; Nais communis var. punjabensis Stephenson, 1909; Nais communis var. caeca Stephenson, 1910; Pterochaeta astronensis Pierantoni, 1911; Nais communis var. acuta Pointner, 1914; Nais communis f. magenta Marcus, 1943.

Record and ecological observations: Found in Rio Claro (MARCUS, 1943), in Monjolinho (ALVES et al., 2006), São Lourenço river (ROSA et al., 2014), in streams of Intervales State Park, Bocaina, Carmo, Lageado and Água Comprida (ALVES et al., 2008) and Bocaina in the Himalaia stream (SANCHES et al., 2016). Associated with sediment in Araraquara in the Santa Clara (ALVES; LUCA, 2000) and Pinheirinho stream (ALVES et al., 2006); in Campos do Jordão in the Campo Meio stream associated with sediment and substrate of erosional and depositional areas (GORNI; ALVES, 2008b). Associated with the sponge Ephydatia crateriformis (Spongillidae), in the Ribeira de Iguape river and the Tietê river (MARCUS, 1943), in São Carlos in the Espraiado stream associated with Radiospongilla amazonenses (Spongillidae) (CORBI et al., 2005; PAMPLIM et al., 2005); Metania spinata (Metaniidae) in Itirapina in the Lagoa Dourada dam (GORNI; ALVES, 2008a); and associated with Pomacea bridgesii (Ampullaridae) (GORNI; ALVES, 2006). Associated to submerged macrophytes in Brotas in Lagoa Dourada (ALVES; GORNI, 2007), to aquatic macrophytes in Luiz Antônio in Infernão Lake (TRIVINHOSTRIXINO et al., 2000), associated to bryophytes in Jacaré-Pepira river (GORNI; ALVES, 2007); in Campos do Jordão, associated with leaflets, in the Galharada streams (GORNI; ALVES, 2012). We found it in the Itupararanga, Paiva Castro, Rio Grande, Promissão and Billings reservoirs.

Nais magnaseta Harman, 1973.

Record and ecological observations: This species was registered in the Promissão reservoir, however, to date this species had not been registered in Brazil, its distribution was limited only to Texas, USA (HARMAN, 1973).

Nais pardalis Piguet, 1906.

Synonyms: Nais bretscheri var. Piguet pardalis, 1906; Nais lastockini Sokolskaya, 1958.

Record and ecological observations: Found in São Paulo in Pinheiros river (MARCUS, 1943), in Araraquara in Pinheirinhos stream (ALVES; LUCCA, 2000; ALVES et al., 2006); association with Pomacea bridgesii (Ampullaridae) (GORNI; ALVES, 2006). We found it in the central body of the Billings and Paiva Castro reservoir.

Nais schubarti Marcus, 1944.

Record and ecological observations: Found in the Paiva Castro reservoir, in the municipality of Franco da Rocha (GIROLLI et al., 2018). We found it in the Itupararanga, Paiva Castro, França and Ponte Nova reservoirs.

Nais variabilis Piguet, 1906.
Record and ecological observations: Found in a stream in Bocaina (SANCHES et al., 2016) and in the Paranapanema river (CESAR; HENRY, 2017); associated with submerged macrophytes in Américo Brasiliense and Brotas, in Anhumas stream and Dourada Lake dams (ALVES; GORNI, 2007); associated with larvae of organisms of the order Odonata in Ipeúna, in the Cantagalo and Lapa streams (CORBI et al., 2004); and Campos do Jordão, in the Galharada stream (GORNI; ALVES, 2015) associated with the leaflets (GORNI; ALVES, 2012) and in substrate of erosional and depositional areas (GORNI; ALVES, 2008b). We found it in the Itupararanga, Paiva Castro, Graminha, Promissão, Ponte Nova reservoirs, and in the Billings reservoir in the central body and in the Rio Pequeno arm.

Slavina evelinae Marcus, 1942.

Synonyms: Peloscolex evelinae Marcus, 1942.

Record and ecological observations: Found in São Paulo on the Pinheiros River (DU BOIS-REYMOND MARCUS, 1944; MARCUS, 1942; 1943); in the Ponte Nova (PAMPLIN et al., 2005) and Bariri reservoirs (PAMPLIN et al., 2005; SURIANI et al., 2007); in Bocaina, in the Himalaia stream (SANCHES et al., 2016). Associated with submerged macrophytes in the municipalities of Américo Brasiliense, at Anhumas stream dam, and Brotas, at Dourada Lake Dam, (ALVES; GORNI, 2007); and Salvinia (Salviniaceae) and Egeria (Hydrocharitaceae) (SANCHES; GORNI, 2014); in Luiz Antônio in the Infernão Lake associated with Scirpus cubensis (Cyperaceae) (CORREIA; TRIVINHO-STRIXINO, 1998); and to aquatic macrophytes (TRIVINHO-STRIXINO et al., 2000); associated with the decaying leaves of Ficus elastic (Rosales: Moraceae) (MARCUS, 1942); Found associated with sediment in Américo Brasiliense, at Anhumas stream dam (CORBI; TRIVINHO-STRIXINO, 2002). We found it in the Paiva Castro and Santa Branca reservoirs.

Stephensoniana trivandrana Aiyer, 1926.

Synonyms: Naidium trivandranum Aiyer, 1926; Stephensonia trivandrana (Aiyer, 1926); Slavinia trivandrana (Aiyer, 1926).

Record and ecological observations: Found in the deep region $( \pm 21 \mathrm{~m})$ of the Promissão reservoir, in the municipality of Promissão (GIROLLI et al., 2019). We found it in the Paiva Castro, Santa Branca, Jurumirim, Promissão and Billings - Rio Pequeno reservoirs.

\section{PRISTININAE SUBFAMILY}

Pristina americana Černosvitov, 1937.

Synonyms: Pristina americana f. typica Cernosvitov, 1937; Pristina americana var. loretana Cernosvitov, 1937; Pristina peruviana Černosvitov, 1939; Pristina longidentata Harman, 1965; Pristinella longidentata Harman, 1965; Pristina orghidani Botea, 1983.

Record and ecological observations: Found in São Paulo on the Pinheiros river (DU BOIS-REYMOND MARCUS 1944; MARCUS 1942; 1943), and on the Tietê River (DU BOIS REYMOND MARCUS 1949; MARCUS 1942; 1943); in the Ponte Nova reservoir (PAMPLIN et al., 2005); in the Monjolinho river (ALVES et al., 2006); in the Bariri reservoir (PAMPLIN et al., 2005; SURIANI et al., 2007). Associated with sediment in Ibitinga, Nova Avanhandava, Três Irmãos, Promissão and Barra Bonita (SURIANI et al., 2007), in Araraquara, in the Pinheirinho streams (ALVES; LUCCA, 2000; ALVES et al., 2006); Santa Clara, in Luiz Antônio, in Diogo Lake (ALVES; STRIXINO, 
2000); in Campos do Jordão, in the Galharada stream (GORNI; ALVES, 2015), associated with leaflets (GORNI; ALVES, 2012), and the substrate of erosional and depositional areas (GORNI; ALVES, 2008b). We found it in Santa Branca, França, Jurumirim, Graminha and Promissão reservoirs.

\section{Pristina longisoma Harman, 1977.}

Synonyms: Pristinella longisoma Haran, 1977.

Record and ecological observations: This species was first registered in the state of São Paulo. The reservoirs where $P$. longisoma occurred were central body Billings, Promissão and Rio Grande. A previous study reports its occurrence in Paraná, in the coastal region of Paranapanema, in the Iguaçú River (MORETTO et al., 2013).

Pristina osborni Walton, 1906 (Figure 3).

Synonyms: Naidium osborni Walton, 1906; Pristinella osborni Walton, 1906; Naidium minutum Stephenson, 1914; Pristinella minuta Stephenson, 1914; Pristina minuta Stephenson, 1914.

Record and ecological observations: Found in São Paulo, associated with aquatic macrophytes of the Bromeliaceae family
(Lamiales), in a stream in Jardim Europa and Jardim Paulista (MARCUS, 1943); at Ribeira de Iguape, the Araquá River (MARCUS, 1943; 1944), and the Guareí River (CESAR; HENRY, 2017), and at the Intervales State Park (ALVES et al., 2008). It was also registered in Américo Brasiliense, at Anhumas stream dam, and in Brotas, at Lagoa Dourada Dam, associated with submerged macrophytes (ALVES; GORNI, 2007); in Campos do Jordão, in the Galharada stream, associated with sediments (GORNI; ALVES, 2012) and in substrates of erosional and depositional areas (GORNI; ALVES, 2008b). We found it in the reservoirs Paiva Castro, Santa Branca, Jurumirim, Promissão, Ponte Nova (Mesotrophic), Rio Grande (Supereutrophic) and Billings (Hypereutrophic), according to Table 3. In fact, a wide range was observed between the variables OM, DO, P, TOC, NKj, Ptot, EC and C, as shown in Table 2.

\section{Pristina probocidea Beddard, 1896.}

Synonyms: Pristina proboscidea f. typica (Beddard, 1896); Pristina proboscidea var. paraguayensis Michaelsen, 1905.

Record and ecological observations: Occurred in Araraquara, in Água Branca stream (ALVES et al., 2006); in São Carlos, associated

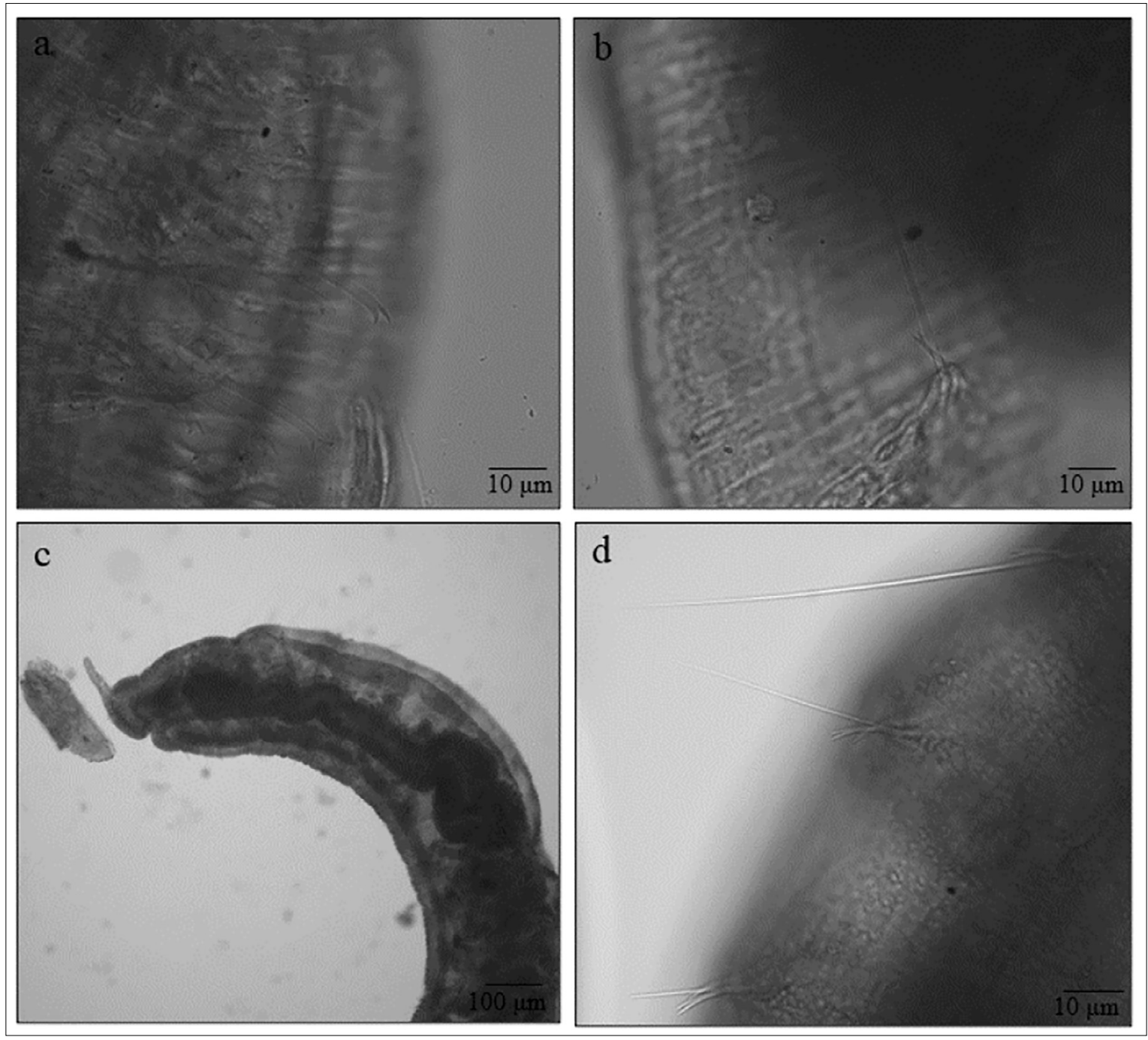

Figure 3. a) Ventral setae of Pristina osborni; b) dorsal setae (hair and needle) of Pristina osborni; c) prostomium with proboscis of Pristina synclites; d) dorsal setae (hair and needle) of Pristina synclites. 
with Radiospongilla amazonensis (Spongillidae) (PAMPLIN et al., 2005), and in the Jacaré-Guaçu River associated with the same organism (CORBI et al., 2005); associated with submerged macrophytes in Américo Brasiliense and Brotas, in Anhumas stream and Dourada Lake dams, respectively (ALVES; GORNI, 2007); associated Salvinia (Salviniaceae) and Egeria (Hydrocharitaceae) (SANCHES; GORNI, 2014); and Campos do Jordão, in the Galharada stream (GORNI; ALVES, 2015), associated with substrates of erosional and depositional areas (GORNI; ALVES, 2008b), and sediments (GORNI; ALVES, 2012). We found it in the Paiva Castro and Ponte Nova reservoirs.

Pristina rosea Piguet, 1906.

Synonyms: Naidium roseum Piguet, 1906; Naidium jenkinae Stephenson, 1931; Pristinella jenkinae Stephenson, 1931; Naidium roseum $f$. jenkinae Stephenson, 1931; Pristina jenkinae Stephenson, 1931; Naidium roseum, Marcus, 1943 (non Piguet); Pristina idrensis Sperber, 1948; Pristinella idrensis Sperber, 1948; Pristina taita Stout, 1956; Pristina nothophagi Stout, 1958.

Record and ecological observations: Found in São Paulo, in the Pinheiros river (DU BOIS-REYMOND MARCUS, 1944; MARCUS, $1942 ; 1943)$ and in the municipality of Bocaina, in the Himalaia and Bocaina streams (SANCHES et al., 2016), in Araraquara, in Água Branca, Gouveia and Pinheirinho streams (ALVES et al., 2006); associated with sediments in São Carlos (ALVES; LUCCA, 2000), in the Monjolinho dam also associated with sediment (FUSARI; FONSECAGESSNER, 2006); in Campos do Jordão, in the Galharada streams (GORNI; ALVES, 2015) associated with sediments (GORNI; ALVES, 2012); and Campo Meio and Serrote associated with substrates of erosional and depositional areas (GORNI; ALVES, 2008b). Associated with Egeria (Hydrocharitaceae) in Américo Brasiliense, Anhumas stream dam (SANCHES; GORNI, 2014), and in Brotas in the JacaréPepira River, associated with bryophytes (GORNI; ALVES, 2007). We found it in the reservoirs Paiva Castro, França, Graminha and Billings.

Pristina synclites Stephenson, 1925 (Figure 3).

Record and ecological observations: Found in São Paulo, on the São Lourenço river (ROSA et al., 2014), and in Bocaina, in the Himalaia and Bocaina streams (SANCHES et al., 2016); associated with sediment in Araraquara, in the Pinheirinho stream (ALVES; LUCCA, 2000; ALVES et al., 2006), and in São Carlos, in the Monjolinho river (ALVES et al., 2006; FUSARI; FONSECA-GESSNER, 2006); associated with Egeria (Hydrocharitaceae) in Américo Brasiliense, at Anhumas stream dam (SANCHES; GORNI, 2014). We found it in the Itupararanga reservoirs, Graminha (Eutrophic) Paiva Castro, França, Jurumirim, Promissão, Ponte Nova (Mesotrophic); and the Billings reservoir in Rio Pequeno (Eutrophic), Taquacetuba and central body (Hypereutrophic). A wide amplitude was observed in these reservoirs between the variables $\mathrm{OM}, \mathrm{DO}, \mathrm{P}, \mathrm{TOC}, \mathrm{NKj}$, Ptot, EC and C, as shown in Table 2.

\section{RHYACODRILINAE SUBFAMILY}

Bothrioneurum sp. Stolc, 1886 (Figure 4).

Record and ecological observations: This genus has 3 species distributed in the state of São Paulo, namely: B. americanum Beddard, 1894, found in Ponte Nova and Bariri reservoirs (PAMPLIN et al., 2005); B. iris Beddard, 1901 found in Sao Paulo: (MARCUS, 1942; 1943; 1944); and B. vejdovskyanum Stolc, 1886 found in the Tietê

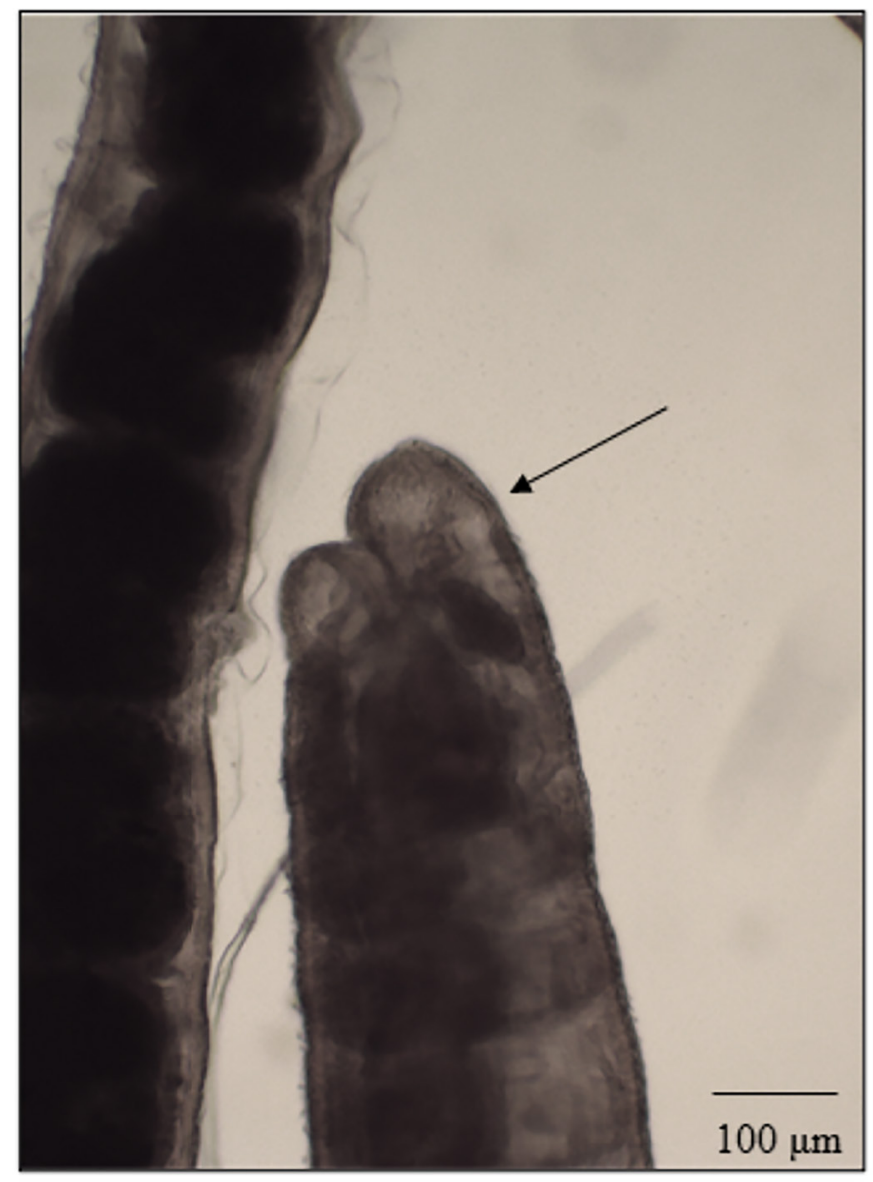

Figure 4. Sensory pit of Bothrioneurum sp.

rivers (DU BOIS-REYMOND MARCUS, 1949; MARCUS, 1942; 1943), Pinheiros (MARCUS, 1943), in a stream in Jardim Europa (MARCUS, 1942; 1943). We found it in all the reservoirs Itupararanga (Eutrophic), Promissão, Ponte Nova, Santa Branca, França, Jurumirim, Paraibuna, Paiva Castro (Mesotrophic), Taiçupeba, Rio Grande (Seupereutrophic), and in the points of the Billings reservoir in Rio Pequeno (Eutrophic), Taquacetuba and central body (Hypereutrophic); except in Graminha. Some biogeographic characteristic, not studied here, may be influencing the non-distribution of this species in this reservoir, because none of the variables measured were in a discrepant way. In other studies, Bothrioneurum sp., it was also identified as a species tolerant to organically enriched environments (BEHREND et al., 2012; GIROLLI, 2019).

\section{Branchiura sowerbyi Beddard, 1892.}

Record and ecological observations: Occurred in the Guareí River (CESAR; HENRY, 2017); in the Ponte Nova reservoir (PAMPLIN et al., 2005); on the Tietê River (DU BOIS-REYMOND MARCUS 1949; MARCUS 1942; 1943); and in the municipalities of Barra Bonita, Ibitinga, Nova Avanhandava, Três Irmãos, Promissão (SURIANI et al., 2007); in Americana, in the Salto Grande reservoir (PAMPLIN et al., 2006; DORNFELD et al., 2006); in São Carlos, at the Monjolinho Dam (FUSARI; FONSESA-GESSNER, 2006); in Mogi-Guaçu, on Diogo Lake (ALVES; STRIXINO, 2000; 2003); and in Bariri (PAMPLIN et al., 2005; SURIANI et al., 2007), all associated with sediment. We found it in the Itupararanga, Paiva Castro, Santa Branca, Rio Grande, 
Promissão, Ponte Nova reservoirs; and the Billings reservoir in the arms of Rio Pequeno and Taquacetuba.

\section{TUBIFICINAE SUBFAMILY}

Aulodrilus pigueti Kowalewski, 1914 (Figure 5).

Record and ecological observations: Found in the Guareí River (CESAR; HENRY, 2017); associated with Egeria (Hydrocharitaceae) in Américo Brasiliense, at Anhumas stream dam (SANCHES; GORNI, 2014); and in Mogi-Guaçu, in Diogo Lake, associated with sediment (ALVES; STRIXINO, 2000; 2003). We found it in the reservoirs Billings central body (Hipereutrophic) and Rio Pequeno, Graminha (Eutrophic), Itupararanga, Promissão, Ponte Nova, Santa Branca, França, Jurumirim, Paraibuna, Paiva Castro (Mesotrophic) and Rio Grande (Supereutrophic). It was verified in the central body of billings reservoir high organic enrichment and low level of DO, according to Table 2. This may have favored the development of $A$. pigueti as dominant species $(55.4 \%$ of the total organisms identified at this point). Other authors such as Prygiel et al., (2000), Ragonha et al. (2013) and Sales et al. (2014), corroborate that $A$. pigueti reaches high densities in environments with great intake of organic matter.
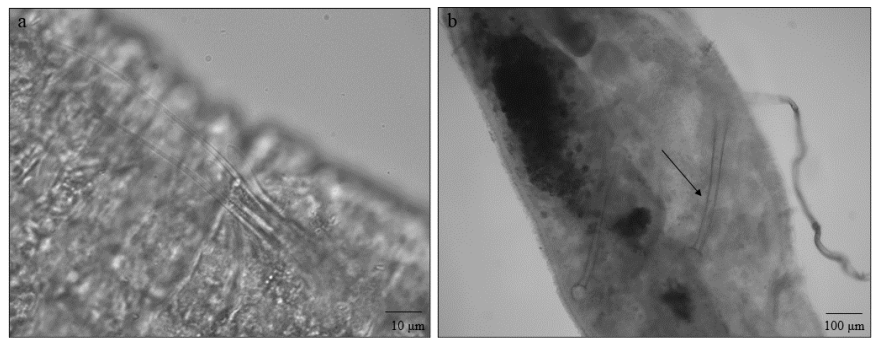

Figure 5. a) Dorsal setae (hair and needle) of Aulodrilus pigueti; b) Penial sheath of Limnodrilus hoffmeisteri.

Limnodrilus hoffmeisteri Claparède, 1862 (Figure 5).

Synonyms: Limnodrilus hoffmeisteri f. typica Claparede, 1862; Clitellio hoffmeisteri Claparède, 1862; Clitellio (Limnodrilus) hoffmeisteri Claparede, 1862; Tubifex hoffmeisteri Claparède, 1862; Camptodrilus spiralis Eisén, 1879; Limnodrilus spiralis Eisén, 1879; Camptodrilus californicus Eisén, 1879; Limnodrilus californicus Eisén, 1879; Clitellio (Limnodrilus) californicus Eisén, 1879; Camptodrilus corallinus Eisén, 1879; Clitellio (Limnodrilus) corallinus Eisén, 1879; Limnodrilus corallinus Eisen, 1879; Limnodrilus dugesi Rybka, 1898; Limnodrilus hoffmeisteri f. dugesi Rybka, 1898; Limnodrilus gotoi (part) Hatai, 1899; Limnodrilus lucasi Benham, 1903; Limnodrilus vejdovskyanus Benham, 1903; Limnodrilus subsalsus (part) Moore, 1905; Limnodrilus aurostriatus Southern, 1909; Limnodrilus aurantiacus Friend, 1911; Limnodrilus hoffmeisteri var. tenellulus Friend, 1912; Limnodrilus socialis Stephenson, 1912; Limnodrilus hoffmeisteri f. socialis Stephenson, 1912; Limnodrilus parvus var. biannulatus Lastockin, 1927; Limnodrilus pacificus Chen, 1940; Limnodrilus hoffmeisteri $f$. divergences Marcus, 1942; Limnodrilus subsalus, Marcus, 1944; Limnodrilus parvus, Du Bois-Reymond Marcus, 1947, Gavrilov \& Tomsic Peace, 1950; Limnodrilus hoffmeisterif. silly Marcus 1942.

Record and ecological observations: This species was found in the Ponte Nova reservoirs (PAMPLIN et al., 2005), Lomoeiro (MARCUS, 1943), in São Paulo (MARCUS, 1942; 1943; 1944); in the São Lourenço river (ROSA et al., 2014); in Bariri (Pamplin et al., 2005; SURIANI et al., 2007); in Americana, on the Atibaia river, in the Salto Grande reservoir (DORNFELD et al., 2006; PAMPLIN et al., 2006); and in a stream in Bocaina (SANCHES et al., 2016). Associated with sediment at all of the following sites, such as Intervales State Park in the Bocaina, Lageado, Rio das Mortes, Roda d'Água, Três Córregos streams (ALVES et al., 2008); in the municipality of Araraquara, in the Pinheirinho streams (ALVES; LUCCA, 2000; ALVES et al., 2006), Água Branca (ALVES et al., 2006) and Santa Clara (ALVES; LUCCA, 2000); in Pirituba (MENDES et al., 1951); in Mogi-Guaçu on the Diogo Lake (ALVES; STRIXINO, 2000; 2003); in São Carlos on the Monjolinho River (ALVES et al., 2006; FUSARI; FONSECA-GESSNER, 2006); in Ribeirão Preto on the Monte Alegre lake (CLETO-FILHO; ARCIFA, 2006); in Campos do Jordão in the Serrote streams, associated with substrate of erosional and depositional areas (GORNI; ALVES, 2008b); and Galharada (GORNI; ALVES, 2015), associated with sediments and sediments (GORNI; ALVES, 2012); also registered in Barra Bonita, Ibitinga, Nova Avanhandava, Três Irmãos and Promissão reservoirs (SURIANI et al., 2007). We found it in the Itupararanga (Eutrophic) reservoirs, Promissão, Ponte Nova, França, Jurumirim, Paraibuna, Paiva Castro (Mesotrophic), Taiçupeba, Rio Grande (Supereutrophic); and in the Billings reservoir in the central body, and in the arms of Taquacetuba (Hypereutrophic) and Rio Pequeno (Eutrophic).

The L. hoffmeisteri species has hemoglobin, which enables them to support low oxygen concentrations (ESTEVES, 1998), and is therefore characterized as an indicator of organically polluted environments (VERDONSCHOT, 1989; PASTERIS et al., 1999; SURIANI et al., 2007; BEHREND et al., 2012; ZHAO; LIU, 2012; ZEYBEK et al., 2018; GORNI et al., 2018; GIROLLI, 2019).

\section{Spirosperma velutina Grube, 1879.}

Synonyms: Saenuris velutina Grube, 1879; Peloscolex velutinus Grube, 1879; Peloscolex velutinus velutinus Grube, 1879; Embolocephalus velutinus Grube, 1879; Spirosperma (Embolocephalus) velutinus Grube, 1879; Psammoryctes velutinus Grube, 1879; Tubifex velutinus Grube, 1879; Tubifex (Peloscolex) velutinus Grube, 1879; Tubifex sarnensis Pierantoni, 1904; Peloscolex velutinus sarnensis Pierantoni, 1904; Peloscolex cernosvitovi Arabic, 1958; Peloscolex fontinalis Arabic, 1964.

Record and ecological observations: Until now there was no record of occurrence of this species in Brazil, its occurrence was recorded only in Venezuela and Europe (CHRISTOFFERSEN, 2007). In this study $S$. velutina occurred in Taiaçupeba reservoirs, Rio Grande, Promissão; and the Billings reservoir in the central body and arms of Rio Pequeno and Taquacetuba.

OPISTOCYSTIDAE FAMILY Černosvitov, 1936

Opistocysta funiculus Cordero, 1948 (Figure 6).

Synonyms: Pristina flagellum, Cernosvitov, 1936 (non Leidy, 1880); Opistocysta flagellum, Marcus, 1944, Du Bois-Reymond Marcus, 1947 (non Leidy, 1880).

Record and ecological observations: Found in Mogi-Guaçu (ALVES; STRIXINO, 2000; 2003), Luiz Antônio (ALVES; STRIXINO, 2000), in Bariri and Ponte Nova reservoirs (PAMPLIN et al., 2005), Americana, at the Atibaia river and Salto Grande reservoir (DORNFELD et al., 2006), Paranapanema river (CESAR; HENRY, 
2017) and Bocaina, in the Himalaia stream (SANCHES et al., 2016). Associated with Egeria (Hydrocharitaceae) (SANCHES; GORNI, 2014) and; associated with sediment in the municipalities of Americana, the Atibaia river and Salto Grande reservoir (DORNFELD et al., 2006; PAMPLIN et al., 2006), Américo Brasiliense, at the Anhumas stream dam (CORBI; TRIVINHO-STRIXINO, 2002), Barra Bonita, Ibitinga, Nova Avanhandava, Três Irmãos (SURIANI et al., 2007), São Paulo on Diogo Lake (MARCUS, 1942; 1943; 1944). We found it in the Paiva Castro, Santa Branca, França, Jurumirim, Promissão, Ponte Nova (Mesotrophic), Rio Grande (Supereutrophic) and Billings reservoirs (Hypereutrophic). O. funiculus, is abundant in organically enriched environments (DORNFELD et al., 2006; GIROLLI, 2019).
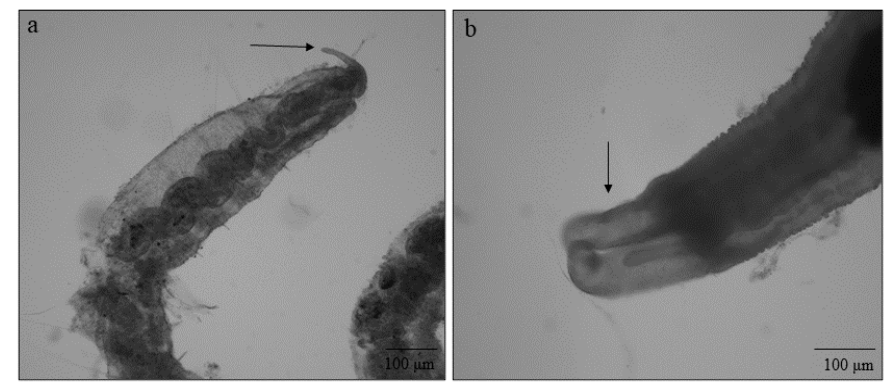

Figure 6. a) Prostomium with proboscis and b) caudal appendages of Opistocysta funiculus.

\section{Finals considerations}

The results presented above make this inventory extremely important for the knowledge of the distribution of aquatic oligochaetes, not only for the State of São Paulo, but throughout the Brazilian territory. Moreover, using the methodology of species accumulation curves and richness estimators, it was found that the sample number of this research was sufficient to obtain a reliable result, since the number of identified species corroborated the richness estimators.

The number of taxa identified (total of 28) in this research was higher than other studies performed in lentic environments in Brazil, such as Suriani et al. (2007) who identified 17 species in São Paulo; in Paraná, Behrend et al. (2012) identified 25 species; Gomes et al. (2017) identified 12 species in Rondônia; and Gorni et al. (2018) who identified 22 species in Mato Grosso. In addition, the identified species represented $36.4 \%$ of the 77 previously recorded species in the State of São Paulo (GORNI et al., 2015; GIROLLI et al., 2018; GIROLLI et al., 2020).

In relation to South America, Christoffersen (2010) claims that the cataloged Oligochaeta represent only a fraction of their true diversity, which emphasizes the need for more studies that contemplate the species inventory in the Neotropical regions. However, it is noteworthy that over the past few years the number of surveys with freshwater Oligochaeta has been growing, especially in Brazil, and there are more than 2,300 surveys between the years 1985 and 2015 (Rodrigues; Alves, 2018).

In this research, the three most abundant species were found in organically enriched reservoirs with low dissolved oxygen levels. This factor favors the development of dominant species, such as Aulodrilus pigueti (55.4\%), Limnodrilus hoffmeisteri (16.4\%) and Bothrioneurum sp. $(7.9 \%)$. Generally, these species are found in sediments with abundant organic matter (Marchese, 1987; Montanholi-Martins; Takeda, 1999; Behrend et al., 2009; Lafont et al., 2012). Other studies (Rosenberg;
Resh, 1993; Popp; Hoagland, 1995; Suriani et al., 2007) show that when one or a few species have high percentages of individuals in the community or assembly, it may be a sign of an environment with a high level of eutrophication or organically enriched. The Billings reservoir showed significant concentrations of nutrients, which can influence the colonization of tolerant taxa (Esteves, 2011).

The Bothrioneurum sp. it is a Tubificinae commonly found in impacted waters, presenting high numerical density, often occurring together with Limnodrilus hoffmeisteri, in organically enriched places, with high conductivity and low oxygenation (Alves; Lucca, 2000). Its tolerance to eutrophication and organic pollution has already been stated by Timm (2009) and Dumnicka (2007). Timm (1997) goes so far as to report that a high level of organic pollution is a limiting factor for the occurrence of the genus. Similarly, L. hoffmeisteri is commonly known as an indicator of eutrophic environments, which explains its frequency in places more intensely influenced by this condition.

Aulodrilus pigueti, which was the most abundant species in this study, is a cosmopolitan organism found in greater density in environments with high conductivity, low to moderate current speed and mud and clay sediments with abundant organic matter. The authors Schenková et al. (2010) collected the species on the bottom substrate of a fish pond and in the submerged coastal vegetation. In addition, Aulodrilus pigueti has the habit of digging the sediment and forming tubes from detritus (Timm; Veldhijzen Van Zanten, 2002). Although the species occurs in lentic or lotic freshwater environments (Finogenova; Arkhipova, 1994; Schloesser et al., 1995; Šporka, 1996), but it demonstrates having preference for environments in which the quality of the water and the substrate present characteristics of oligo to mesotrophic trophic level (Šporka, 2003), and is able to tolerate smaller amounts of dissolved oxygen and acidification (Orciari; Hummon, 1975). These characteristics reinforce the expressive occurrence of the species in intensely eutrophic reservoirs, showing its possible preference for lentic waters, rich in nutrients and with high conductivity.

The high trophic level can provide a series of microhabitats for Oligochaeta, such as surface macrophytes and sediments with abundant availability of organic matter. Notably, for Naidinae, microorganisms associated with macrophytes, such as epiphytic algae, bacteria and protozoa, are important sources of food (Brinkhurst; Jamieson, 1971; Alves; Gorni, 2007; Timm; Martin, 2015). On the other hand, tubificinae reach high abundances in the superficial layers of the sediment with a high concentration of total organic carbon, nitrogen and organic matter (Brinkhurst; Jamieson, 1971). Lin and Yo (2008), studying the effect of organic pollution on the distribution of Oligochaeta found the highest values for species richness, abundance and diversity in the sites with the greatest organic enrichment. Several other authors point out that high numbers of the total of Oligochaeta occur when the environment is highly polluted (Chapman et al., 1980; Rosenberg; Resh, 1993; Suriani et al., 2007).

The enriched reservoirs showed high metabolic potentials, where the organic load present in the sediment favored diversity of species and abundance of the Oligochaeta. However, they have low ecological quality, as they do not present the expressive occurrence of sensitive species. In general, sensitive species occurred in a low percentage in all reservoirs. However, it should be noted that the list of sensitive species was based on Lafont et al. (2012) for temperate environments, with the need for a functional survey for neotropical taxa, aiming at the biomonitoring of water and sediment quality. 
In this context, inventories of oligochaete fauna and ecological relationships between species and the environment are very important for the formulation of biodiversity conservation policies, especially in tropical environments (Christoffersen, 2010; Rodrigues; Alves, 2018). Studies of oligochaete assemblage patterns can be useful to predict changes along environmental gradients, as well for standardized methods for testing organisms in ecotoxicological studies (Castro et al., 2020; Suriani et al., 2007; Behrend et al., 2012). However, oligochaete species surveryed and systematics studies still are scarce in Brazilian environments, probably due to the lack of specialists in the taxonomic identification of these worms.

Finally, further research using the Oligochaeta class is necessary due to its importance as bioindicators of water quality and sediment associated with the unique characteristics of Brazilian continental ecosystems.

\section{Acknowledgements}

We are grateful to the Water Communities Sector (ELHC) of the Environmental Company of the State of São Paulo - CETESB, especially to the biologists Monica Luisa Kuhlmann and Hélio Rubens Victorino Imbimbo for the authorization of access to the Oligochaeta Collection of Monitoring Network. This research was supported by FAPESP (São Paulo Research Foundation), Process Number 2018/12069-9, and the Coordination for the Improvement of Higher Education Personnel (CAPES).

\section{Author Contributions}

Douglas Aparecido Girolli: Substantial contribution in the concept and design of the study; Contribution to data collection; Contribution to data analysis and interpretation; Contribution to manuscript preparation; Contribution to critical revision, adding intelectual content.

Mariana Futenma de Lima: Contribution to data analysis and interpretation; Contribution to manuscript preparation.

Nathalie Aparecida de Oliveira Sanches: Contribution to data analysis and interpretation; Contribution to manuscript preparation.

Vanessa Colombo-Corbi: Contribution to manuscript preparation.

Juliano José Corbi: Substantial contribution in the concept and design of the study; Contribution to data analysis and interpretation; Contribution to manuscript preparation.

Guilherme Rossi Gorni: Substantial contribution in the concept and design of the study; Contribution to data collection; Contribution to data analysis and interpretation; Contribution to manuscript preparation; Contribution to critical revision, adding intelectual content.

\section{Conflicts of interest}

The authors declare that they have no conflict of interest related to the publication of this manuscript.

\section{References}

AGOSTINHO, A. A.; THOMAZ, S.M.; GOMES, L.C. 2005. Conservação da biodiversidade em águas continentais do Brasil. Megadiversidade, Paraná, v.1, n.1, p. 70-78.

ALVES, R. G.; GORNI, G. R. 2007. Naididae species (Oligochaeta) associated with submersed aquatic macrophytes in two reservoirs (São Paulo, Brazil). Acta Limnologica Brasiliensia, v.19, n. 4, p. 407-413.
ALVES, R. G.; LUCCA, J. V. 2000. Oligochaeta (Annelida: Clitellata) como indicador de poluição orgânica em dois córregos pertencentes à Bacia do Ribeirão do Ouro - Araraquara (São Paulo-Brasil). Brazilian Journal of Ecology, v. 4, n. 1-2, p. 112-117.

ALVES, R. G.; MARCHESE, M. R.; ESCARPINATI, S. C. 2006. Oligochaeta (Annelida, Clitellata) in lotic environments in the state of São Paulo, Brazil. Iheringia. Série Zoologia, v. 96, n. 4, p. 431-435.

ALVES, R. G.; MARCHESE, M. R.; MARTINS, R. T. 2008. Oligochaeta (Annelida, Clitellata) of lotic environments at Parque Estadual Intervales (São Paulo, Brasil). Biota Neotropica, v. 8, n. 1, p. 69-72.

ALVES, R. G.; STRIXINO, G. 2000. Distribuição espacial de Oligochaeta em uma lagoa marginal do rio Mogi-Guaçu-SP. Iheringia, Série Zoologia, v. 88, p.173-180.

ALVES, R. G.; STRIXINO, G. 2003. The sampling of benthic macroinvertebrates using two different methods: waiting trays and an Ekman collector. Acta Limnologica Brasiliensia, v.15, n. 3, p. 1-6.

BEHREND, R. D. L, FERNANDES, S. E. P., FUJITA, D. S., TAKEDA, A. M. 2009. Eight years of monitoring aquatic Oligochaeta from the Baía and Ivinhema Rivers. Brazilian Journal of Biology, v. 69, n. 2, pp. 559-571.

BEHREND, R. D. L.; TAKEDA, A. M.; GOMES, L. C.; FERNANDES, S. E. P. 2012. Using Oligochaeta assemblages as an indicator of environmental changes. Brazilian Journal of Biology, São Carlos, v. 72, n. 4, p. 873-884.

BRINKHURST, R. O.; JAMIESON, B. G. M. 1971. Aquatic Oligochaeta of the world. University of Toronto Press, p. 860.

BRINKHURST, R. O.; GELDER, S. R. 1991. Annelida: oligochaeta and branchiobdellida. Ecology and classification of North American freshwater invertebrates, 401-428.

BRINKURST, R. O.; MARCHESE, M. R. 2008. Guia para la identificación de oligoquetos acuáticos continentales de Sud y Centroamerica. Santa Fé: Asociación de ciências naturales del litoral, Santa Fé, p. 207, 1989. Campinas, v. 8, n. 1, p. 69-72.

CASTRO, G. B.; PINHEIRO, F. R.; FELIPE, M. C.; BERNEGOSSI, A. C.; GIROLLI, D.; GORNI, G. R.; CORBI, J. J. 2020. Update on the use of Pristina longiseta Ehrenberg, 1828 (Oligochaeta: Naididae) as a toxicity test organism. Environmental Science and Pollution Research, p. 1-10.

CESAR, D. A. S.; HENRY, R. 2017. Is similar the distribution of Chironomidae (Diptera) and Oligochaeta (Annelida, Clitellata) in a river and a lateral fluvial area?. Acta Limnologica Brasiliensia, 29.

CETESB L5.309. 2003. Determinação de bentos de água doce Macroinvertebrados: Métodos qualitativo e quantitativo. São Paulo, p. 16. Disponível em: $<\mathrm{http}: / /$ cetesb.sp.gov.br/normas-tecnicas-cetesb/normastecnicas-vigentes/>. Acesso em: 27/09/2017.

CETESB, São Paulo. 2015. Qualidade das águas interiores no estado de São Paulo 2014. São Paulo, p. 540. Disponível em: <http://aguasinteriores. cetesb.sp.gov.br/publicacoes-e-relatorios/>.

CETESB, São Paulo. 2016. Qualidade das águas interiores no estado de São Paulo 2015. São Paulo, p. 562. Disponível em: <http://aguasinteriores. cetesb.sp.gov.br/publicacoes-e-relatorios/>.

CETESB, São Paulo. 2017. Qualidade das águas interiores no estado de São Paulo 2016. São Paulo, p. 287. Disponível em: <http://aguasinteriores. cetesb.sp.gov.br/publicacoes-e-relatorios/>.

CHAPMAN, P. M.; CHURCHALAND, L. M.; THOMSON, P. A.; MICHNOWSKY, E. 1980. Heavy metal studies with oligochaetes. In: Brinkhurst, R.O. \& Cook, D.G. (eds.) Aquatic oligochaete biology. Plenum Press, New York. p.477-502.

CHRISTOFFERSEN, M. L. 2007. A catalogue of aquatic microdrile oligochaetes (Annelida: Clitellata) from South America. Acta Hydrobiologica Sinica, v. 31, p. 59-86.

CHRISTOFFERSEN, M. L. 2010. Continental biodiversity of South American oligochaetes: The importance of inventories. Acta Zoológica Mexicana (NS), 26(2).

CLETO-FILHO, S. E. N.; ARCIFA, M. S. 2006. Horizontal distribution and temporal variation of the zoobenthos of a tropical Brazilian lake. Acta Limnologica Brasiliensia. v.18, n.4, p. 407-421. 
CORBI, J. J.; JANCSO, M. A.; TRIVINHO-STRIXINO, S.; FRAGOSO, E. N 2004. Occurence of Oligochaeta living on larvae of Odonata from Ipeúna (São Paulo state, Brazil). Biota neotropica, v.4, n2, p. 1-3.

CORBI, J. J.; TRIVINHO-STRIXINO, S. 2002. Spatial and bathymetric distribution macrobenthic fauna of the Ribeirão das Anhumas reservoir (Américo Brasiliense-SP, Brasil). Acta limnol. bras., v. 14, n. 1, p. 35-42.

CORBI, J. J.; TRIVINHO-STRIXINO, S.; ALVES, R. G. 2005. Records of oligochaetes in freshwater sponges, on bryozoans and on colonial hydrozoans from Brazil. Brazilian Journal of Biology, v.65, n.1, p.187-188.

CORREIA, L.C.S.; TRIVINHO-STRIXINO, S. 1998. Macroinvertebrados da Rizosfera de Scirpus cubensis na lagoa do Infernão (Estação Ecológica de Jataí - SP): Estrutura e função. Acta Limnologica Brasiliensia, v.10, n.1, p. $37-47$.

DORNFELD, C.B.; ALVES, R.G.; LEITE, M.A.; ESPÍNDOLA, E.L.G. 2006. Oligochaeta in eutrofic reservoir: the case of Salto Grande reservoir and their main affluent (Americana, São Paulo, Brazil). Acta Limnologica Brasiliensia, v.18, n.2, p.189-197.

DU BOIS-REYMOND MARCUS, E. 1944. Notes on fresh-water oligochaeta from Brazil. Comunicaciones Zoologicas del Museo de Historia Natural de Montevideo, v. 1, n. 20.

DU BOIS-REYMOND MARCUS, E. 1949. Further notes on naidids and tubificids from Brazil. Com. Zool. del Mus. Montevideo. 51(3) 1-15.

DUMNICKA, E. 2007. Distribution of Oligochaeta in various littoral habitats in the anthropogenic reservoirs. Oceanological and Hydrobiological Studies, v. 36, n. Suppl. 4.

ESTEVES, F. A. 1998. Fundamentos de limnologia. $2^{\circ}$ ed. Rio de Janeiro: Interciência, p. 602.

ESTEVES, F. A. 2011. Fundamentos de Limnologia. $3^{\mathrm{a}}$ edição. Interciência, Rio de Janeiro.

FINOGENOVA, N. P.; ARKHIPOVA, N. R. 1994. Morphology of some species of the genus Aulodrilus Bretscher. Hydrobiologia, 278, 7-15.

FUSARI, L. M; FONSECA-GESSNER, A. A. 2006. Environmental assessment of two small reservoirs in southeastern Brazil, using macroinvertebrate community metrics. Acta Limnologica Brasiliensia, v. 18, n.1, p. 89-99.

GIROLLI, D. A.; GORNI, G. R.; COLOMBO-CORBI, V.; CORBI, J. J. 2018. First record of Nais schubarti Marcus, 1944 (Oligochaeta: Naidinae) in the State of São Paulo. Braz. J. Biol.. Disponível em: http://dx.doi. org/10.1590/1519-6984.189084.

GIROLLI, D. A.; GORNI, G. R.; COLOMBO-CORBI, V.; CORBI, J. J. 2020. First record of Stephensoniana trivandrana Aiyer, 1926 (Oligochaeta: Naididae), in southeastern Brazil. Braz. J. Biol., v. 80, n. 2, p. 476-478.

GIROLLI, D. A. 2019. Oligochaeta (Annelida: CLITELLATA) como indicadores da qualidade da água e sedimento em reservatórios no Estado de São Paulo. Dissertação de Mestrado, p. 74.

GOMES, D. F.; SANCHES, N. A. O.; SAHM, L. H.; GORNI, G. R. 2017. Aquatic oligochaeta (Annelida: Clitellata) in extractive reserve Lake Cuniã, Western Brazilian Amazon. Biota Neotropica, 17(1).

GORNI, G. R.; ALVES, R. G. 2006. Naididae (Annelida, Oligochaeta) associated with Pomacea bridgesii (Reeve) (Gastropoda, Ampullaridae). Revista Brasileira de Zoologia, v. 23, n. 4, p. 1059-1061.

GORNI, G. R.; ALVES, R. G. 2007. Naididae (Annelida, Oligochaeta) associated with briophytes in Brotas, State of São Paulo, Brazil. Revista Brasileira de Zoologia, v.24, n.2, p. 518-519.

GORNI, G. R. 2007. Oligochaeta (Annelida: Clitellata) em córregos de baixa ordem do Parque Estadual de Campos do Jordão (São Paulo, Brasil). Dissertação de Mestrado, Universidade Federal de Juiz de Fora, UFJF,

GORNI, G. R.; ALVES, R. G. 2008a. Naididae species (Annelida: Oligochaeta) associated with the sponge Metania spinata (Carter, 1881) (Porifera: Metaniidae) from a southeastern Brazilian reservoir. Acta Limnologica Brasiliensia, v. 20, n. 3, p. 261-263.

GORNI, G. R.; ALVES, R. G. 2008b. Oligochaeta (Annelida: Clitellata) em córregos de baixa ordem do Parque Estadual de Campos do Jordão (São Paulo-Brasil). Biota Neotropica, v. 8, n. 4, p. 161-165
GORNI, G. R.; ALVES, R. G. 2012. Oligochaetes (Annelida, Clitellata) in a neotropical stream: a mesohabitat approach. Iheringia. Série Zoologia, v. 102 , n. 1, p. 106-110.

GORNI, G. R.; ALVES, R. G. 2015. Influência de variáveis ambientais sobre a comunidade de oligoquetos (Annelida: Clitellata) em um córrego neotropical. Biotemas, v. 28, n. 1, p. 59-66.

GORNI, G. R.; PEIRÓ, D. F.; SANCHES, N. 2015. Aquatic Oligochaeta (Annelida: Clitellata) from State of São Paulo, Brazil: Diversity and Ocurrence review. Biota Neotropica, Campinas, v. 15, n. 1, p. 1-8.

GORNI, G. R., SANCHES, N. A. D. O., COLOMBO-CORBI, V., \& CORBI, J. J. 2018. Oligochaeta (Annelida: Clitellata) in the Juruena River, MT, Brazil: species indicators of substrate types. Biota Neotropica, 18(4).

HARMAN, Walter J. 1973. New species of Oligochaeta (Naididae) with additional distributional records from Oklahoma and Texas. The Southwestern Naturalist, p.151-164.

LAFONT, M. 1989. Contribution à la gestion des eaux continentales: utilisation des oligochètes comme descripteurs de l'état biologique et du degré de pollution des eaux et des sédiments. Thèse de Doctoral. d'Etat ès Sciences. UCBL, Lyon I, France, p. 403.

LAFONT, M.; TIXIER, G.; MARSALEK, J.; JÉZÉQUEL, C.; BREIL, P.; SCHMITT, L. 2012. From research to operational biomonitoring of freshwaters: a suggested conceptual framework and practical solutions. Ecohydrology \& hydrobiology, 12(1), p. 9-20.

LIN, K.; YO, S. 2008. The effect of organic pollution on the abundance and distribution of aquatic oligochaetes in an urban water basin, Taiwan. Hydrobiologia, v. 596, n. 1, p. 213-223.

MARCHESE, M. R. 1987. The ecology of some benthic Oligochaeta from the Paraná River, Argentina. In: Aquatic Oligochaeta. Springer, Dordrecht, $p$. 209-214.

MARCUS, E. 1942. Sobre algumas Tubificidae do Brasil. Boletim da faculdade de Filosofia, Ciências e Letras da Universidade de São Paulo Zoologia v. 25, n.6, p. $153-228$.

MARCUS, E. 1943. Sobre Naididae do Brasil. Boletim da Faculdade de Filosofia, Ciências e Letras da Universidade de São Paulo Zoologia. v. 32, n.7, p.3-247.

MARCUS, E. 1944. Sobre Oligochaeta límnicos do Brasil. Boletim da Faculdade de Filosofia, Ciências e Letras da Universidade de São Paulo Zoologia.v.43, n.8, p.5-135.

MARTIN, P.; MARTINEZ-ANSEMIL, E.; PINDER, A.; TIMM, T.; WETZEL, M. J. 2008. Global diversity of oligochaetous clitellates ("Oligochaeta"; Clitellata) in freshwater. Hydrobiologia 595: 117-127.

MARTINS, R. T.; ALVES, R. G. 2008. Occurrence of Naididae (Annelida: Oligochaeta) from three gastropod species in irrigation fields in southeastern Brazil. Biota Neotropica, v. 8, n. 3, p. 254-257.

MENDES, E. G.; PÉREZ GONZÁLEZ, M. D; COUTINHO, M. L. 1951. On the function of hemoglobine in limnic Oligochaeta. Bol. Fac. Fil. Ci. Letr. Univ. S. Paulo. 16: p. 289-301

MONTANHOLI-MARTINS, M. C.; TAKEDA, A. M. 1999. Spatial and temporal variation of Oligochaeta (1993-1994) in the main and a secondary channel of the Rio Paraná, Brazil. Stud. Neotrop. Fauna \& Environm, 34, 52-58.

MORETTO, Y.; SIMÕES, N. R.; BENEDITO, E.; HIGUTI, J. 2013. Effect of trophic status and sediment particle size on diversity and abundance of aquatic Oligochaeta (Annelida) in neotropical reservoirs. Annales de Limnologie - International Journal of Limnology, v.49, n.1, p.65-78.

ORCIARI, R.D.; HUMMON, W.D. 1975. A comparison of benthic Oligochaete populations in acid and neutral lentic environments in southeastern Ohio. Ohio Journal of Science, 77, 44-49.

PAMPLIN, P. A. Z.; ALMEIDA, T. C. M.; ROCHA, O. 2006. Composition and distribution of benthic macroinvertebrados in Americana Reservoir (SP, Brazil). Acta Limnologica Brasiliensia v.18, n.2, p. 121-132.

PAMPLIN, P. A. Z.; ROCHA, O.; MARCHESE, M. 2005. Riqueza de espécies de Oligochaeta (Annelida: Clitellata) em duas represas do rio Tietê (São Paulo). Biota Neotropica, Campinas, v.5, n.1, p. 63-70.

PASTERIS, A.; VECCHI, M.; BONOMI, G. 1999. A comparison among different population models for Limnodrilus hoffmeisteri Claparède (Oligochaeta, Tubificidae). Hydrobiologia, 406, p. 183-189. 
POPP, A.; HOAGLAND, K. D. 1995. Changes in benthic community composition in response to reservoir aging. Hydrobiologia, 306, p. 159-171.

PRYGIEL, J.; ROSSO-DARMET, A.; LAFONT, M.; LESNIAK, C.; OUDDANE, B. 2000. Use of oligochaete communities for assessment of ecotoxicological risk in fine sediment of rivers and canals of the ArtoisPicardie water basin (France). Hydrobiologia 410, p. 25-37.

R CORE TEAM. R. 2017. A Language and Environment for Statistical Computing. R Foundation for Statistical Computing, Vienna, Austria.

RAGONHA, F. H.; TAKEDA, A. M. 2014. Does richness of Oligochaeta (Annelida) follows a linear distribution with habitat structural heterogenety in aquatic sediments? Journal of limnology, v. 73, n.1, p. 146-156.

RIGHI, G. 1984. Manual de identificação de invertebrados límnicos do Brasil. $\mathrm{CNPq} /$ Coordenação Editorial, Brasília, p. 48.

ROCHA, O. 2003. Avaliação do estado do conhecimento da diversidade biológica do Brasil. In Águas Doces. Projeto Estratégia Nacional de Diversidade Biológica (Bra 97 G 31). Brasilia: Ministerio do Meio Ambiente, p. 70.

RODRIGUES, L. F. T.; ALVES, R. D. G. 2018. Global panorama of studies about freshwater oligochaetes: main trends and gaps. Papéis Avulsos de Zoologia, v. 58, p.1-6.

ROSA, B. F. J. V.; MARTINS, R. T.; ALVES, R. G. 2015. Distribution of oligochaetes in a stream in the Atlantic Forest in southeastern Brazil. Brazilian Journal of Biology, v. 75, n. 1, p. 1-7.

ROSA, B. J. F. V.; RODRIGUES, L. F. T.; OLIVEIRA, G. S.; ALVES, R. G. 2014. Chironomidae and Oligochaeta for water quality evaluation in an urban river in southeastern Brazil. Environmental monitoring and assessment, v. 186, n. 11, p. 7771-7779.

ROSENBERG, D. M.; RESH, V. H. 1993. Freshwater biomonitoring and benthic macroinvertebrates. Chapman \& Hall, New York. p. 488.

ROSSO, A. 1995.Description de l'impact des micropolluants sur les peuplements d'oligochètes des sédiments de cours d'eau du bassin-versant de l'Ill (Alsace). Elaboration d'une méthode biologique de diagnostic de l'incidence des micropolluants. Doctoral dissertation, Thèse de Doctorat, Université Lyon I: p. 232.

SALES, P. C. L.; RODRIGUES, E. I.; DE DEUS, M. D. S. M.; LOPE, M. S.; RAGONHA, F. H.; TAKEDA, A. M. 2014. Oligochaeta do Estado do Piauí. Arquivos do Museu Dinâmico Interdisciplinar, 18(2), p. 1-4.

SANCHES, N. A. O.; GORNI, G. R. 2014. Preferência de Habitat de Oligochaeta (Annelida, Clitellata) em Macrófitas Aquáticas na Represa Ribeirão das Anhumas (Américo Brasiliense-Sp). ReBraM, v. 17, n. 1, p. 165-173.

SANCHES, N. A. O.; SAHM, L. H.; GOMES, D. F. 2016. Inventário de oligochaeta (Annelida: Clitellata) em córregos urbanos de Bocaina-SP, Brasil. ReBraM, v. 19, n. 1, p. 14-24.

SCHENKOVA, J., PAŘIL, P., PETŘIVALSKÁ, K., \& BOJKOVÁ, J. 2010. Aquatic oligochaetes (Annelida: Clitellata) of the Czech Republic: checklist, new records, and ecological remarks. Zootaxa, 2676(1), 29-44.
SCHLOESSER, D.W., REYNOLDSON, T.B.; MANNY, B.A. 1995. Oligochaete fauna of Western Lake Erie 1961 and 1982: signs of sediment quality recovery. Journal of Great Lake research, 21(3), 294-306.

ŠPORKA, F.1996 First record of Aulodrilus pigueti (Oligochaeta, Tubificidae) from the Morava River in Slovakia. Biologia, 51(5), 494.

ŠPORKA, F. 2003. Polychaeta, Oligochaeta. In: Šporka, F. Slovak aquatic macroinvertebrates. Checklist and catalogue of autecological notes, Slovenský hydrometeorologický ústav, Bratislava, pp. 88-96.

SURIANI, A. L.; FRANÇA, R. S.; PAMPLIN, P. A. Z.; MARCHESE, M.; LUCCA, J. V.; ROCHA, O. 2007. Species richness and distribution of oligochaetes in six reservoirs on Middle and Low Tietê River (SP, Brazil). Acta Limnologica Brasiliensia, v.19, n. 4, p.415-426.

TAKEDA, A. M.; CALLISTO, M.; PERREIRA, F.; BARBOSA, A. R. 2000. Zoobenthos survey of the pantanal, Mato Grosso do Sul, Brazil, In: P. W. Willink, B. Chernoff, L. E. Alonso, J. R. Montambault \& R. Lourival (eds), Rapid Assessment Program, 49-55.

TIMM, T. 2009. A guide to the freshwater Oligochaeta and Polychaeta of Northern and Central Europe. Lauterbornia 66: p. 1-235.

TIMM, T.; MARTIN, P. J. 2015. Clitellata: oligochaeta. In Thorp and Covich's Freshwater Invertebrates, Academic Press, p. 529-549. doi.org/10.1016/ B978-0-12-385026-3.00021-8

TIMM, T., ERSÉUS, C.; LUNDBERG, S. 1997. New and unusual records of freshwater Oligochaeta from the Scandinavian Peninsula. Nordic Journal of Freshwater Research, 72 (1996), 15-29.

TIMM, T.; VELDHIJZEN VAN ZANTEN, H.H. 2002. Freshwater Oligochaeta of North-West Europe. CD-ROM. Center for Taxonomic Identification (ETI) and University of Amsterdam, the Netherlands.

TRIVINHO-STRIXINO, S.; CORREIA, L. C. S.; SONODA, K. 2000. Phytophilous Chironomidae (Diptera) and other macroinvertebrates in the ox-bow Infernão Lake (Jataí Ecological Station, Luiz Antônio, SP, Brazil). Revista Brasileira de Biologia, v.60, n.3, p.527-535.

VERDONSCHOT, P. F. 1989. The role of oligochaetes in the management of waters. In Aquatic Oligochaete Biology, p. 213-227.

VIVIEN, R.; TIXIER, G.; LAFONT, M. 2014. Use of oligochaete communities for assessing the quality of sediments in watercourses of the Geneva area (Switzerland) and Artois-Picardie basin (France): proposition of heavy metal toxicity thresholds. Ecohydrology \& Hydrobiology, 14(2), p. 142-151.

ZEYBEK, M.; ŞAHIN, S. K.; YILDIZ, S. 2018. The Aquatic Oligochaeta (Annelida) Fauna of the Karasu Stream. LIMNOFISH 4(1): p.30-35.

ZHAO, Y.; LIU, X. 2012. Community structure of macrozoobenthos in the lettoral zone of the Chaohu lake. Resour. Environ. Yangtze Basin 21, p.39-44.

Received: $12 / 11 / 2020$

Revised: 28/04/2021

Accepted: 04/05/2021

Published online: 28/05/2021 